\title{
ZARZĄDZANIE W OŚWIACIE A KOMPETENCJE PSYCHOLOGICZNE DYREKTORÓW
}

\section{Abstract \\ Management in education, and psychological competencies of headmasters}

The article discusses school management issues, and focuses on selected areas of psychological competence, personality issues mainly in terms of autonomy and sense of agency. These considerations are accompanied by reflection on managerial effectiveness and critical remarks on the competition procedures in school.

Keywords: psychological competence, management in education, school headmaster, personality

\section{Streszczenie}

W artykule poruszono tematykę zarządzania szkołą, skoncentrowano się na wybranych obszarach problematyki kompetencji psychologicznych oraz kwestiach osobowościowych rozumianych głównie w kategoriach autonomii i poczucia sprawstwa. Rozważaniom towarzyszy refleksja nad skutecznością kierowniczą i krytyczne uwagi na temat procedur konkursów dyrektorskich w szkole.

Słowa kluczowe: kompetencje psychologiczne, zarządzanie w oświacie, dyrektor szkoły, osobowość

Współczesna codzienność to czas immanentnej zmiany dokonującej się w niemal wszystkich dziedzinach życia. Sytuacja ta sprawia, że także instytucje oświatowe funkcjonują w nurcie nieustannych przeobrażeń. Czynniki demograficzne, przemiany technologiczne, rozwój gospodarki, wiedzy itp. nie pozostają bez wpływu na kompleksową strukturę systemu oświaty, pracę konkretnych placówek i wymagania wysuwane względem ich personelu. Ta „turbulentna” rzeczywistość wyznacza zasięg i charakter zmian [Banaszak, 2013: 68-69]. W świetle rosnących oczekiwań stawianych polskim szkołom warto spojrzeć na role, jakie pełnią one w całym systemie społecznym. Szersza perspektywa pomoże kształtować procesy 
adaptacyjne i założenia reformatorskie w taki sposób, by polska szkoła i jej menedżerowie mogli lepiej stawić czoła nowym wymaganiom i spełnić pokładane w nich nadzieje.

\section{Współczesna szkoła — kierunki zmian i odpowiedzialność środowiska}

Od lat dziewięćdziesiątych XX wieku, z uwagi na wprowadzone wówczas zmiany $\mathrm{w}$ polskim prawie oświatowym, w sposób istotny zmieniła się specyfika funkcjonowania szkół [UoSO, 1991]. Z instytucji statycznej, reaktywnej i silnie zbiurokratyzowanej szkoła miała stać się organizacją dynamiczną, kreatywną i wizjonerską, w myśl idei „organizacji uczącej się” [Witek, 2000: 7; Jeżowski, 2007: 37-39; Kazimierowicz, 2008].

Podążając wyznaczoną drogą, obecna szkoła coraz wyraźniej pełni funkcję usługową wobec swoich uczniów i ich rodziców, coraz silniej podkreśla się też jej rynkowy charakter i kładzie nacisk na standaryzację efektów. Ten kierunek, pod jednymi względami słuszny, pod innymi budzić może wątpliwości. Patrząc na współczesną polską szkołę, mimo uznanych w świecie sukcesów naszych wyników edukacyjnych, warto zastanowić się nad niek tórymi kwestiami nieco głębiej i zadbać, by w tej rynkowej retoryce nie zagubić istoty edukacji i wychowania. Środowisko edukacyjne powinno zabiegać, by nie deprecjonować wartości wiedzy „niekomercyjnej”, nie pozbawiać autorytetu pedagoga - mentora/mistrza czy wreszcie nie dopuścić do stłumienia twórczego, niekonwencjonalnego myślenia. Sami nauczyciele winni upominać się o własną autonomię i prorozwojowe rozumienie wartości nauki, o wychowanie rozumiane w kategoriach procesu, relacji i wartości, nie koncentrując się przy tym na krzewieniu ,jedynie słusznego" takiego czy innego światopoglądu, wpisywaniu uwag w dzienniczku czy rankingach. Pojawiające się wątpliwości co do realizacji nowych wymagań wynikają tu nie tyle z krytyki fundamentalnych oczekiwań formułowanych względem systemu oświaty, ile są raczej efektem obserwacji często bolesnego zderzenia założeń polityki z praktyką edukacyjną.

Jak kiedyś, tak i dzisiaj zadania stojące przed systemem oświaty są ważne $\mathrm{i}$ trudne. Obecnie jednak zmienny kontekst współczesnego świata nadaje szkołom nowy charakter, dynamicznie otwierając kolejne obszary problemowe. Szkolna rzeczywistość wykraczająca daleko poza działania stricte edukacyjne musi sprostać wielu złożonym społeczno-gospodarczym wyzwaniom. To, jak projektowana jest przestrzeń edukacyjno-wychowawcza i podejmowane w jej ramach działania, staje się kluczowe, przekłada się bowiem nie tylko na jednostkowe biografie uczniów i nauczycieli, ale także tworzy kontekst dla budowania potencjału społeczności lokalnej czy szerzej - całego społeczeństwa, stanowiąc o jego poziomie rozwoju, konkurencyjności i wyznawanych wartościach. W tym kontekście wydaje się, że nie da się urzeczywistnić pożądanej wizji oświaty bez otwartych, autonomicznych, zaangażowanych i dobrze przygotowanych, prorozwojowych przywódców edukacyjnych, ludzi, którzy przyjmą na siebie odpowiedzialność 
i podołają wyzwaniom. Nie dziwi zatem dyskusja i koncentracja uwagi różnych środowisk wokół zagadnień związanych z przygotowaniem zawodowym, profilami osobowościowymi kadry zarządzającej (dyrektorów) i procesami ich weryfikacji.

\section{Funkcja zarządcza dyrektora}

W przywołanych reformach z lat dziewięćdziesiątych XX wieku dostrzeżono konieczność włączenia w system edukacji myślenia w kategoriach menedżerskich [UoSO, 1991; Rozporządzenie..., 1999]. Świadomość potrzeby bardziej systematycznego kierowania szkołami znalazła swoje odzwierciedlenie w regulacjach prawnych. Przegląd wymagań stawianych dyrektorom i analiza ramowych programów studiów i kursów kwalifikacyjnych z zarzadzania w oświacie wskazały na dominację twardych treści menedżerskich, związanych z tradycyjnym ujęciem tej funkcji, zamykając jej znaczenie głównie w sferze formalnoprawnej [Rozporządzenie..., 1999]. Jeszcze kilka lat temu podejście to było charakterystyczne dla myślenia o kierowaniu szkołą i przygotowaniu jej kadry kierowniczej. Starano się wprost przetransponować ogólne założenia teorii organizacji i zarządzania na teren szkoły. $Z$ czasem zaczęto dostrzegać ograniczenia przyjętej perspektywy i zwrócono uwagę na specyfikę warunków oświatowych i edukacyjnych wartości, postulując uwzględnienie ich w procesie przygotowania do pełnienia funkcji dyrektora i codziennej praktyki kierowniczej [Bottery, 1992; Dorczak, 2009, 2012]. W konsekwencji pojawiła się konieczność wypracowania nowoczesnego spojrzenia na procesy zarządzania w oświacie, redefinicji funkcji i kompetencji dyrektora oraz zmian w systemach kształcenia kadry kierowniczej dla szkół. W szerszym, europejskim kontekście szybko dostrzeżono ten problem, jednak w Polsce opracowane na początku lat dziewięćdziesiątych regulacje prawne, mimo upływu przeszło 20 lat, pozostały niemal w niezmienionej formie [OECD 2012; Rada Unii Europejskiej, 2013]. Trzeba jednak zaznaczyć, że przy braku nowych, kompleksowych rozwiązań legislacyjnych także w naszym kraju zmienia się świadomość społeczna i oczekiwania stawiane szkołom i ich dyrektorom. W świetle obowiązujących przepisów znacznie poszerzył się zakres dyrektorskich zadań i odpowiedzialności. Dyrektor zyskał dużą swobodę decyzyjną, zarówno w kwestiach kadrowych, jak i organizacyjnych. Charakterystyczne dla końca ubiegłego wieku menedżerskie spojrzenie na oświatę było oczywiście perspektywą słuszną, jednak doświadczenia ostatnich lat skłaniają do wniosków, że zarówno teoria, jak i praktyka zarządzania wymagają pogłębionej refleksji w kierunku znaczenia przywództwa edukacyjnego i psychologicznych charakterystyk menedżerów oświaty. Współczesna szkoła jest płaszczyzną, na której ścierają się różne interesy, wartości i oczekiwania. By móc odpowiedzialnie wypełniać swoje podstawowe funkcje, instytucja ta potrzebuje kogoś, kto będzie w stanie sprostać presji i nowym wyzwaniom. Jak wskazują Richard DuFour i Robert Marzano, ,jakość pracy kadr kierowniczych szkół coraz częściej jest uznawana za jeden z kluczowych czynników przyczyniających 
się do sukcesu edukacyjnego uczniów, szkół i całych systemów edukacyjnych" [za: Dorczak, 2015: 15].

Szkoła, jak każda inna organizacja, jest ustrukturalizowanym systemem społeczno-technicznym, w ramach którego współwystępują podsystemy: celów i wartości, psychospołeczny, struktury, techniczny i zarządzania [Griffin, 1999; Krzyżanowski, 1999: 34-35]. Ten ostatni kontroluje wszystkie pozostałe. Na powyższe elementy można zatem spojrzeć jak na charakterystykę zadań menedżerskich, wyznaczających obszar kierowniczych wpływów. Z perspektywy kierownika cel, jakim jest powodzenie organizacji, można rozumieć jako sukces instytucji lub jako realizację potrzeb, zamierzeń i ambicji jej członków [por. Zieleniewski, 1979; Koźmiński, Obój 1989; Koźmiński, Piotrowski, 2010]. Niezależnie od przyjętej perspektywy wskazuje się na systemowy charakter organizacji, gdzie zmiana w jednym podsystemie pociąga za sobą konieczność adaptacyjną w pozostałych. Dla przykładu: zwiększenie naboru uczniów generuje pytania o liczebność klas i jakość kształcenia, wpływa na procesy kadrowe, pojawia się kwestia doposażenia klas czy bibliotek itd.

Umiejętność odnalezienia się w gąszczu prawnych, sytuacyjnych i personalnych kontekstów powinna przekładać się na wysokie wymagania kwalifikacyjne i kompetencyjne względem kadry zarządzającej koordynującej wszystkie powyższe procesy. Zatem aby jakość funkcjonowania szkół była coraz wyższa, szczególnego znaczenia nabiera profesjonalizm kierownictwa placówki, który rozpatrywać powinno się zarówno w kategoriach zadaniowych, jak i kategoriach przywódczych.

W Polsce stanowisko dyrektora szkoły powierza się na drodze konkursu. Może nim zostać osoba, która spełni określone warunki formalne [UoSO, 1991, art. 36; Michalak, 2006; Pielachowski, 2007; Goriszowski, 2008; Bednarska-Wnuk, 2006]. Dyrektor szkoły jest przedstawicielem administracji publicznej, stąd jego zadania należy rozpatrywać w szerokiej perspektywie. Według Henry’ego Mintzberga role menedżera wynikające $\mathrm{z}$ formalnej pozycji w strukturze hierarchii sprowadzić można do trzech zasadniczych kategorii: informacyjnej, interpersonalnej i decyzyjnej [Mintzberg, 1990]. Z punktu widzenia skuteczności i profesjonalizmu dyrektora na plan pierwszy wysuwa się proces zarzadzania, rozumiany jako zestaw działań (obejmujących planowanie, podejmowanie decyzji, organizowanie i przewodzenie, kontrolę) skierowanych na zasoby organizacji (ludzkie, finansowe, rzeczowe, informacyjne) i wykonywanych z zamiarem osiągnięcia celów organizacji w sposób sprawny (mądre wykorzystanie zasobów) i skuteczny (właściwe decyzje) [Griffin, 2004]. W szkole o poprawności realizacji poszczególnych zadań decydują kwalifikacje i kompetencje [UoSO, 1991, art. 16, 19, 39; KN art. 42; Witek, 2000: 80; Pielachowski 2001: 93-96; Kurzyna-Chmiel, 2009: 131-133; Bednarska-Wnuk, 2008: 18]. Zasadniczo funkcje dyrektora podzielić można na te wynikające z pozycji lidera i władzy formalnej, do których zalicza się decyzje organizacyjne, kadrowe, finansowe i administracyjne, oraz te niekierownicze, związane z działalnością dydaktyczną i opiekuńczo-wychowawczą. Większość powyższych kwestii sprowadza się do bardziej tradycyjnego, menedżerskiego rozumienia roli dyrektora. W szerszym kontekście codzienność kierownicza to swoista wędrówka przez chaos, zamienianie potencjalnego konfliktu w kooperację, 
praca na potencjale i nieustanne bycie „w relacji”, a to już wymaga czegoś więcej, niż tylko formalnych umiejętności zarządczych. Zdaniem Romana Dorczaka dostrzeżenie społecznego wymiaru organizacji wymaga od kierowników posiadania pewnych specyficznych właściwości i zwrócenia w swojej pracy uwagi na takie istotne wartości, jak m.in. sprawiedliwość, wolność, szacunek, zaufanie, odpowiedzialność, odwaga, otwartość, współpraca, refleksyjność [Mazurkiewicz, Dorczak, 2015: 19-20]. Współcześnie w myśli i praktyce organizacyjnej znaczenia nabierają nie tyle zasoby ludzkie, ile kapitał społeczny organizacji, a więc już nie tylko skutecznie wykorzystane zasoby, lecz także tworzone relacje międzyludzkie stają się wiodącym czynnikiem ewaluacji menedżerskiego (organizacyjnego) sukcesu. Władzę ujmuje się nie tylko w kategorii posiadania czy panowania, ale też jako dynamiczny proces alokacji szans decydowania w organizacji, bez sztywnego gorsetu struktur formalnych, ze złożoną mozaiką wzajemnych wpływów i relacji [Doktór, 2009: 33]. Warto jednak pamiętać, że w szkole to dyrektor odpowiada za poziom poinformowania, umiejętności i zaangażowania swoich pracowników i ostatecznie ponosi odpowiedzialność za wypracowane rozwiązania i podjęte decyzje. By móc sprostać wyzwaniom dyrektorskiej codzienności, przyjąć na siebie takie obciążenia i zobowiązania, nie wystarczą uzyskane kwalifikacje i po raz kolejny znaczenia nabierają właściwości psychologiczne.

\section{Kompetencje psychologiczne dyrektorów - wybrane aspekty}

Zdaniem wielu tylko niezależny, charyzmatyczny dyrektor może stanowić źródło inspiracji dla uczniów, ich rodziców i podwładnych. Mając na uwadze określone cele organizacyjne, przywódca rozbudza potencjał tkwiący w każdym członku organizacji, którą zarządza. Budowanie prorozwojowej kultury organizacyjnej i kapitału społecznego oraz wzmacnianie zaangażowania wymaga jednak określonych kompetencji psychologicznych. Zasadniczo kompetencje zdefiniować można jako zakres uprawnień bądź zestaw doświadczeń, wiedzy, umiejętności i odpowiedzialności [szerzej: Słownik języka polskiego, 2005: 348; Oleksyn, 2010; Kacprzak, Król, 2014: 41-46; Furmanek, 1997; Orczyk, 2009; Strykowski, 2005]. Na potrzeby prowadzonych tu rozważań kompetencje psychologiczne dyrektora rozumiane będą jako zestaw specyficznych predyspozycji i cech osobowościowych. $Z$ uwagi na ograniczenia wydawnicze skoncentrowano się na wybranych obszarach tej szerokiej kategorii, starając się utrzymać założenie Kazimierza Szewczyka, że kompetencja psychologiczna wykazuje wyraźny związek z autonomią [Szewczyk, 2009]. Pomocne było tu także stanowisko Fiony Patterson [2001], w myśl którego sukces w aktywności zawodowej można odnieść zwłaszcza wtedy, kiedy ma się świadomość celów, do jakich się dąży, i kontrolę nad prowadzącymi do ich realizacji działaniami. Zdaniem przywołanej autorki wiąże się to z posiadaniem dość szczególnych osobistych kompetencji, związanych przede wszystkim z poczuciem sprawstwa, ze zdolnością do świadomego samorozwoju, wewnętrznej motywacji i odpowiedzialności [Patterson, 2001]. 
Osadzenie problematyki nowoczesnego zarządzania szkołą w kontekście psychologicznym, otwiera szerokie pole naukowych dociekań [Tołwińska, 2011; Pyżalski, 2014; Dorczak, Kołodziejczak, 2015]. Obiektywne ograniczenia skłaniają jednak do zawężenia perspektywy. Wiążąc kompetencje psychologiczne głównie z kategoriami osobowościowymi, skupiono się na motywacji rozumianej przede wszystkim w kategoriach potencjału, samorozwoju i przyjemności, zwrócono uwagę na wewnątrz- i zewnątrzsterowność, poczucie kontroli, ideę poziomów osobistego działania i wybraną teorię cech. Wskazane elementy nie wypełniają pojęcia kompetencji psychologicznych, są jedynie selektywnym zbiorem, który w swym zasadniczym ujęciu, stanowić może punkt wyjścia wyznaczania szerszych kryteriów psychologicznych służących ocenie jakości przywództwa i efektywności organizacji.

Mając na uwadze różnorodne tendencje obecne w dyskursie nad nową filozofią kierowania szkołą [Thomas i in., 2000; Mazurkiewicz, Dorczak, 2015; Oleksyn, 2014; Mazurkiewicz, 2012; Tucker i in., 2012; Kwiatkowski i in., 2011; Orczyk, 2009; Penc, 2007; Tołwińska, 2011; Pyżalski, 2014; Dorczak, Kołodziejczak, 2015], warto odwołać się do klasyki, przenosząc kontekst indywidualnego rozwoju na płaszczyznę organizacyjną.

Koncepcje motywacji skupione na wykorzystaniu własnego potencjału i potrzebie samorozwoju w celu osiągania określonych celów spopularyzowane zostały już w latach sześćdziesiątych XX wieku. Wśród prekursorów podejścia opartego na potencjale wspomnieć należy Carla Rogersa i Abrahama Maslowa. Rogers zakładał, że pragnienie samorealizacji to fundament motywacji działań jednostki, Maslow skupił się na potrzebach, zamykając ludzkie motywy w strukturę hierarchiczną - wychodząc od potrzeb fizjologicznych, na samorealizacji kończąc [Maslow, 1990; Rogers, 1980]. Mimo upływu lat koncepcje humanistyczne nadal wpływają na filozofię kierowania i stanowić mogą inspirację dla codziennej praktyki menedżerskiej. Kontynuację myśli wspomnianych badaczy odnajdujemy w pracach Edwarda Deciego i Richarda Ryana [1985, 1991] dotyczących motywacji wewnętrznej i tzw. teorii samodeterminacji. Koncepcjom tym przyświecało przekonanie, że ludzie posiadają wrodzoną potrzebę i zdolność podejmowania wyzwań oraz rozwijania własnych zainteresowań i zdolności. Skłonności te badacze określili kategorią motywacji wewnętrznej, w której podejmowanym wysiłkom nie towarzyszy stymulacja zewnętrzna w postaci zachęt, uzyskanych korzyści czy nagród. Idąc dalej w swych poglądach, autorzy głosili tezę, że jeśli działanie odbywa się pod presją lub jest jej efektem (ocena, rywalizacja, groźba), to wówczas mamy do czynienia z osłabieniem motywacji wewnętrznej i w konsekwencji spadkiem zaangażowania. I odwrotnie, jeśli człowiek sam wyznacza sobie cele i zadania, motywacja wewnętrzna rośnie [Deci, Ryan, 1985, 1991; Pervin, John, 2002: 138]. W tym kontekście znaczenia nabiera także koncepcja doświadczeń optymalnych i przepływu (flow) autorstwa Mihályego Csíkszentmihályiego [1975]. Autor zwrócił uwagę na znaczenie przyjemności jako motywatora podejmowanych działań. Wskazał, że skłonni jesteśmy wykonywać wiele zadań, pomimo iż nie niesie to ze sobą żadnych tradycyjnie rozumianych korzyści, a to, co nas wówczas motywuje, to właśnie czerpanie przyjemności z samej aktywności. Jednostka, odczuwając 
przyjemność, angażuje się w daną czynność, jednak w przypadku presji czasu, zagrożenia, zewnętrznych wymagań i obostrzeń motywacja spada [Csíkszentmihályi, 1975; Pervin, John, 2002: 139]. Warto w tym miejscu przywołać jeszcze poglądy Davida Riesmana [2011] dotyczące wewnątrz- i zewnątrzsterowności. W prezentowanym stanowisku pojęcie funkcjonalnej wewnątrzsterowności zastąpiło przystosowanie oparte na transmisji kulturowej (tradycji). W kulturach (społeczeństwach) wewnątrzsterownych mamy do czynienia z poszerzaniem możliwości jednostkowego wyboru i wpływu. Osoby, które w okresie dzieciństwa i adolescencji podlegały transmisji i testowaniu norm i wartości, konstruują pewien ich zestaw, nadający kurs ich egzystencji. Wpojone i wypracowane wartości stanowią fundament, na którym nadbudowuje się kolejne zestawy celów - dzięki nim jednostka potrafi utrzymać równowagę między własnymi celami a presją otoczenia. W tym ujęciu ludzie wewnątrzsterowni są bardziej niezależni i samowystarczalni, mają też silniejsze poczucie panowania nad własnym życiem. W przypadku osób zewnątrzsterownych siłą nadającą kierunek działaniu są inni, ich akceptacja i oczekiwania. Także Walter Reckless w swej teorii kontroli społecznej posłużył się pojęciem wewnątrz- i zewnątrzsterowności, dowodząc, że osoba wewnątrzsterowna dobrze toleruje wieloznaczność, jest niezależna i samodzielna, zdolna do podejmowania decyzji i brania odpowiedzialności za ich konsekwencje. Z kolei ludzie zewnątrzsterowni są skłonni ulegać wpływom innych (polecenia, rozkazy, instrukcje itp.). W skrajnych przypadkach osoby zaliczane do pierwszej grupy mogą być pozbawione empatii i w postawach swych nie liczyć się z otoczeniem, mogą też doświadczać wyobcowania i wykluczenia, natomiast w postawie zewnątrzsterownej charakterystyczne są: konformizm, mało twórcze podejście do problemów, jednowymiarowe postrzeganie świata, brak samodzielności i wyuczona bezradność (Sęk i in., 1998). Powyższe rozważania korespondują z Rotterowskim wymiarem umiejscowienia kontroli (locus of control). Zasadnicza różnica w tych podejściach wynika z przyjętego przez Recklessa założenia o istocie pochodzenia informacji, które wpływają na ludzkie zachowanie, podczas gdy Julian Rotter akcentuje procesy atrybucji, które tworzy człowiek, by zrozumieć otaczającą rzeczywistość. Ludzie dążą do zaspokojenia swoich potrzeb na drodze zachowań instrumentalnych niosących wzmocnienia. Gdy owe wzmocnienia postrzegane są jako konsekwencja własnych działań, wówczas mówimy o wewnętrznym poczuciu kontroli, z kolei osoby z zewnętrznym poczuciem kontroli motywy sprawcze i efekty działań upatrują w czynnikach zewnętrznych. Ludzie z wewnętrznym poczuciem kontroli są bardziej samodzielni, mają wyższe aspiracje i silniej się angażują, towarzyszy im przekonanie, że to, co się wydarza, jest zależne od nich samych. Są sterowani przez wartości i cele zaszczepione im we wczesnym okresie życia w procesie socjalizacji, są bardziej odporni na wpływy społeczne, mniej konformistyczni i bardziej niezależni, podejmują decyzje rozważniej (dłużej się zastanawiają wraz ze wzrostem trudności), inaczej reagują na zadania, do których rozwiązania potrzebne są umiejętności, niż na te oparte na przypadku, silniej koncentrują się na tych pierwszych. Przekładając to na praktykę kierowniczą, przyjąć można, że szefowie z wewnętrznym poczuciem kontroli uważać będą, że nagroda jest uzależniona od ich własnego zachowania i osobistych przymiotów, że świat 
jest przewidywalny, a działania człowieka mają swoje konsekwencje. Z kolei tym sterowanym zewnętrznie towarzyszyć będzie przekonanie, że to, co im się przydarza, zdeterminowane jest przez siły zewnętrzne (los, przypadek, inne osoby obdarzone władzą, nieprzewidywalne wydarzenie itp.). W rezultacie są bardziej wrażliwi na wpływ społeczny, w ich działaniu nie występuje różnica w stopniu koncentracji i roztargnienia w trakcie rozwiązywania zadań wymagających umiejętności względem tych, których rozwiązanie zależy od przypadku. Uważają, że nagrody pojawiają się niezależnie od ich działań i są pod kontrolą sił zewnętrznych, że świat jest nieprzewidywalny, a zachowanie człowieka nie musi prowadzić do nagrody czy uniknięcia przykrości (kary) [Rotter, 1966, 1990; Drwal, 1995; Juczyński, 2001]. Z dużym prawdopodobieństwem można przyjąć, że sprawniejsi i skuteczniejsi w decyzjach i działaniu będą menedżerowie z grupy pierwszej.

Warto w tym miejscu przytoczyć ideę poziomów osobistego działania autorstwa Robina R Vallachera i Daniela M. Wegnera. Koncepcja ta ma swoje źródło w teorii identyfikacji działania, zgodnie z którą identyfikacja oznacza uchwycenie, rozpoznanie lub nadanie znaczenia określonej czynności. U autorów nadanie znaczenia czynności jest równoznaczne z identyfikacją. W uproszczeniu można powiedzieć, że nadając czynności znaczenie, różni ludzie używają różnych poziomów identyfikacji. Niski poziom sprowadza się do powierzchownej, pobieżnej oceny działań, wysoki łączy się z dogłębną, wielowymiarową analizą i interpretacją zdarzeń. Przyjęcie powyższych kryteriów umożliwia podział na dwie zasadnicze grupy ludzi: osoby typu ,jak działam” i typu „dlaczego działam”. Z punktu widzenia predyspozycji zawodowych, efektywności pracy menedżerskiej i roli przy wódczej wydaje się to dość istotne. Osoby typu pierwszego identyfikują działania na poziomie niskim. Szybko się zniechęcają, popełniają wiele błędów, czerpią niższą satysfakcję z wykonywanych czynności, bywają postrzegane jako impulsywne, słabiej zmotywowane, bardziej konformistyczne, o zewnętrznej kontroli wzmocnień. Z kolei osoby typu „dlaczego” formułują identyfikację działania na poziomie głębokim. Koncentracja na znaczeniu czynności sprzyja większej motywacji, działania stają się bardziej efektywne, rzadziej podlegają zakłóceniom zewnętrznym. Osoby takie są bardziej nonkonformistyczne i odporne na ocenę społeczną. Przeważa u nich, oparta na systemie celów i wartości osobistych, wewnętrzna kontrola zachowania [Vallacher, Wegner, 1989: 660-671; Martynowicz, 2003: 117-119].

Wpisując problematykę osobowościową w dyskurs o zarządzaniu, warto jeszcze odwołać się do teorii cech [Kwiatkowski, Michalak, 2010]. Z funkcjonalnego punktu widzenia na uwagę zasługuje psychometryczne podejście Paula T. Costy i Roberta R. McCrae. Autorzy opracowali kwestionariusz pomiaru pięciu czynników osobowościowych (neurotyczność, ekstrawersja, otwartość na doświadczenia, ugodowość i sumienność), który - oparty na solidnych fundamentach teoretycznych - stanowić może praktyczne narzędzie diagnostyczne i weryfikacyjne zarazem [Costa, McCrae, 1992; Zawadzki i in., 1995]. Mimo że teorie cech nie dają jednoznacznej odpowiedzi na pytanie, jakie konstelacje cech stanowią domenę skutecznych liderów, a całościowe profile osobowościowe nie przekładają się wprost na efektywność menedżerską, to jednak trudno lekceważyć ich 
założenia. Spoglądając na „wielką piątkę” nie tylko z perspektywy skuteczności działań i decyzji, ale także przez pryzmat interakcji międzyludzkich, tworzonej atmosfery i warunków pracy oraz zdrowia psychicznego samych kierowników, można przyjąć z dużym prawdopodobieństwem, że w zadaniach dyrektorskich lepiej sprawdzi się kandydat stabilny emocjonalnie, przychylny ludziom, z twórczą wyobraźnią, zmotywowany, zaangażowany, nastawiony na współpracę i rzetelny.

Z powyższych rozważań wyłania się pożądany zestaw predyspozycji oczekiwanych od dobrego (skutecznego) dyrektora. Badania Murraya R. Barricka i Michaela K. Mounta potwierdzają, że z efektywnością zawodową koreluje sumienność, ekstrawersja i otwartość [Jarmuż, 1998: 163-166]. Z kolei Jose F. Solgado wykazał, że najsilniej skorelowane są z nią sumienność i stabilność emocjonalna [Solgado, 1997: 30-34]. Oba te wnioski przełożone na praktykę oświatową wydają się spójne nie tylko ze zdroworozsądkowym myśleniem o stanowisku menedżerskim w szkole, ale także wiążą się z oczekiwaniami samego środowiska nauczycielskiego, ujawnionymi w badaniach autorki [w opracowaniu].

By pozostać przy terminologii Rottera - zasadne wydaje się także, by dyrektor należał do osób z wewnętrznym poczuciem kontroli. Są to bowiem jednostki autonomiczne, silniej zmotywowane i skoncentrowane na celu, świadome swojego potencjału i biorące odpowiedzialność za efekty własnych działań. O ile wskazany kierunek kierowniczej dyspozycji jest raczej bezdyskusyjny, z klinicznego punktu widzenia pamiętać należy o zagrożeniach wynikających ze skrajnego natężenia wewnętrznego poczucia kontroli. Mowa tu zarówno o możliwych zaburzeniach somatycznych, jak i psychicznych. Ludzie o takim rysie osobowościowym mogą ponosić negatywne psychologiczne obciążenia, będące efektem odnoszenia wszystkiego, co im się w życiu przydarza, wyłącznie do własnego potencjału. W przypadku powtarzających się sukcesów może kształtować się u nich poczucie omnipotencji, w sytuacji porażek zaś może to wpływać na samoocenę, obniżając poczucie własnej wartości. Skrajne wewnętrzne poczucie kontroli może też prowadzić do nadmiernego obciążenia zadaniami i stać się przyczyną wypalenia zawodowego. Generalnie jednak wyważona wewnątrzsterowność i wewnętrzne poczucie kontroli stanowić powinny atrybut dobrego menedżera. W próbach wskazania „pożądanych właściwości” potencjalnych dyrektorów szkół wartość dodaną stanowić będzie swoiste poczucie flow. Założenie to wymaga, by kierownicze stanowiska zajmowały osoby sumienne, które w wypełnianiu obowiązków zawodowych odnajdują zadowolenie i satysfakcję, czyniąc z pracy własną pasję. Emocjonalny stosunek do zadań zawodowych, ciekawość poznawcza, motywacja i chęć rozwoju często idą w parze z charyzmą. Osoby takie łatwo zdobywają uznanie otoczenia i stanowią swoisty przykład wart naśladowania. By jednak w pełni docenić koncepcję przypływu, w ocenie profesjonalizmu kadry zarządzającej w oświacie należy nieco inaczej rozłożyć akcenty i przestać myśleć o sukcesie szkoły wyłącznie przez pryzmat rozkładów normalnych i policzalnych efektów. Taka zmiana perspektywy może przyczynić się do zwiększenia zaangażowania i lepszych wyników całej placówki, stanowić fundament rekonstrukcji postaw części nauczycieli i uczniów, którzy za przykładem dyrektora porzucą 
obraz pracownika-wyrobnika, pracy i nauki jako smutnej konieczności, na rzecz wizji rozwojowej, w której podjęta aktywność prowadzi do samorealizacji i satysfakcji zawodowej.

\section{Refleksja końcowa}

Powyższe wskazania dotyczą nie tylko teoretycznych aspektów procesów motywacyjnych i rozwojowych menedżerów czy ich określonych charakterystyk, ale mają także wymiar praktyczny i utylitarny. Profile osobowościowe w połączeniu z wyznawaną filozofią kierowania, menedżerską wiedzą i kwalifikacjami decydować mogą o profesjonalnym zarządzaniu i sprawnym przywództwie. Zasadne wydaje się, by uwzględniając specyfikę placówki i kierowniczych zadań, wypracować katalog pożądanych predyspozycji osobowościowych dyrektora. We współczesnej, dynamicznej rzeczywistości względnie stałe, określone kompetencje psychologiczne mogą okazać się kluczowe, tworzyć tarczę chroniącą psychikę przed specyficznymi zagrożeniami oraz zwiększać gwarancje satysfakcji i zawodowej skuteczności.

Analizując rzeczywistość oświatową, dostrzega się tendencje zmierzające w kierunku zrozumienia znaczenia przywódczej roli dyrektorów szkół i ich potencjału w tym obszarze. Warto, by poszła za tym głębsza refleksja samego środowiska oświatowego, jak i osób stanowiących prawo, prowadząca do krytycznego przyjrzenia się procedurom konkursowym i wymogom stawianym kandydatom. Wymiar polityczny jest tu o tyle istotny, że wszelkie zmiany formalne wymagają zmian legislacyjnych. Nowelizacje są konieczne, gdyż konsekwencją obecnych regulacji prawnych jest sztywność często fikcyjnego postępowania rekrutacyjnego i selekcyjnego, w którym brakuje skutecznej strategii, metody i umiejętności identyfikacji predyspozycji psychologicznych kandydatów. Wątpliwości budzi już sam skład komisji, gdzie zauważalna jest nadreprezentacja przedstawicieli organu prowadzącego i nadzoru, brakuje natomiast specjalistów/ekspertów, którzy w sposób profesjonalny mogliby wesprzeć ten jakże ważny proces kadrowy. Dotychczas w procedurze powierzania stanowiska nie sformułowano w sposób wiążący żadnych koniecznych zdolności i umiejętności społecznych oraz pożądanych profili psychologicznych wynikających bezpośrednio z charakteru stanowiska i specyfiki środowiska pracy. W konsekwencji brakuje też wskazań dotyczących procedur sprawdzających. Wprawdzie panuje powszechne przekonanie, że osoba dyrektora powinna odznaczać się określonymi cechami, takimi jak: stabilność emocjonalna, sprawiedliwość, niezależność, zaangażowanie itp., ma ono jednak charakter nieformalny i dość ogólny. Obecnie po spełnieniu wymogów dotyczących kwalifikacji pozostałe kwestie zależą od ocen, oczekiwań, subiektywnych kryteriów i siły wpływu poszczególnych członków komisji. Procedura skoncentrowana na formalnym doświadczeniu zawodowym sprawia, że ryzyko pominięcia istotnych dla skuteczności kierowniczej kompetencji pozostaje wysokie.

Reasumując, punktem wyjścia prowadzonych rozważań było założenie, że głównym źródłem skutecznych zmian w środowisku edukacyjnym i sukcesu szkół są 
ich liderzy. $Z$ uwagi na ograniczenia wydawnicze w artykule skoncentrowano się na wybranych aspektach problemu kompetencji psychologicznych, temacie ważnym, choć często bagatelizowanym zarówno w badaniach naukowych, praktyce szkolnej, jak i politycznym spojrzeniu na oświatę.

Intencją było zwrócenie uwagi na problem, który nadal pozostaje na marginesie dyskursu o skutecznym przywództwie edukacyjnym, oraz skłonienie do refleksji i krytycznej oceny oświatowej rzeczywistości. Istnieją podstawy teoretyczne, narzędzia, społeczne i rynkowe uzasadnienie, by zarówno do myślenia o profesjonalnej kadrze zarządzającej w szkołach, jak i do samego konkursu dyrektorskiego wprowadzić kryteria psychologicznych kompetencji. Sceptykom takiego rozwiązania pozostawiam do rozważenia wariant, w którym w najgorszym razie spełnienie przez kandydatów tych dodatkowych wymogów nie wpłynie na poprawę pracy i wizerunku szkoły, zachowując status quo, w najlepszym zaś poprawi jakość wyników oraz pozytywnie odmieni oblicze instytucji i wszystkich współtworzących ją osób.

\section{Bibliografia}

Banaszak S. (2013), Zarzadzanie oświata w turbulentnym otoczeniu, „Studia Edukacyjne”, 27.

Bednarska-Wnuk I. (2006), Dyrektor-pedagog menedżer, „Edukacja i Dialog”, 2.

Bednarska-Wnuk I. (2008), Czas na planowanie, „Dyrektor Szkoły”, 9.

Bottery M. (1992), The Ethics of Educational Management, Cassell, London.

Costa P.T. Jr., McCrae R.R. (1992), Four Ways Five Factors Are Basic, „Personality and Differences", 13, 653-665.

Csíkszentmihályi M. (1975), Beyond Boredom and Anxiety, Jossey-Bass CA, San Francisco.

Deci E.L., Ryan R.M. (1985), Intrinsic Motivation and Self-determination in Human Behavior, Plenum, New York.

Deci E.L., Ryan R.M. (1991), A Motivational Approach to Self: Integration in Personality, „Nebraska Symposium on Motivation”, 38.

Doktór K. (2009), Zarządcy bez wiedzy - specjaliści bez władzy? [w:] S. Banaszak, K. Doktór (red.), Socjologiczne, pedagogiczne i psychologiczne problemy organizacji i zarzadzania, Wydawnictwo WSKiZ, Poznań.

Dorczak R. (2009), Zarzadzanie w edukacji - wyzwania i możliwości, „Zarządzanie Publiczne", 2(6), 11-26.

Dorczak R. (2012), Specyfika zarzadzania w edukacji - rozwój indywidualny człowieka jako wartość centralna, „Zarządzanie Publiczne”, 3(19), 42-52.

Dorczak R. (2015), Zarzadzanie i przywództwo w edukacji - gdzie jesteśmy i dokąd zmierzamy [w:] G. Mazurkiewicz, R. Dorczak (red.), Przywództwo edukacyjne. Próba zmiany, Wydawnictwo Uniwersytetu Jagiellońskiego, Kraków.

Dorczak R., Kołodziejczak J. (red.) (2015), Kompetencje przywódcze kadry kierowniczej szkół i placówek oświatowych w Polsce. Raport z badań, Wydawnictwo Uniwersytetu Jagiellońskiego, Kraków. 
Drwal R. (1995), Poczucie kontroli jako wymiar osobowości-podstawy teoretyczne, techniki badawcze i wyniki badań [w:] R. Drwal (red.), Adaptacja kwestionariuszy osobowości. Wybrane zagadnienia i techniki, Wydawnictwo Naukowe PWN, Warszawa.

Furmanek W. (1997), Kompetencje - próba określenia pojęcia, „Edukacja Ogólnotechniczna", 7.

Goriszowski W. (2008), Menedżeryzm oświatowy w teorii i praktyce. Poradnik z zakresu organizacji i kierowania w podnoszeniu efektów pracy szkoty (dla studentów pedagogiki), Wydawnictwo Adam Marszałek, Toruń.

Griffin R.W. (1999), Management, Houghton Mifflin Company, Boston-New York.

Griffin R.W. (2004), Podstawy zarzadzania organizacjami, tłum. M. Rusiński, Wydawnictwo Naukowe PWN, Warszawa.

Jarmuż S. (1998), Zastosowanie modelu „Wielkiej Piatki” $w$ doborze i ocenie personelu [w:] T. Witkowski (red.), Nowoczesne metody doboru i oceny personelu, Profesjonalna Szkoła Biznesu, Kraków.

Jeżowski A. (2007), Obsługa finansowa szkót, „Dyrektor Szkoły”, 2.

Juczyński Z. (2001), Narzędzia pomiaru w promocji i psychologii zdrowia, Pracownia Testów Psychologicznych PTP, Warszawa.

Kacprzak M., Król A. (2014), Strategiczne kompetencje kadry menedżerskiej a rynek pra$c y$, ,Zarządzanie. Teoria i Praktyka” (Wyższa Szkoła Menedżerska w Warszawie), 2(10).

Kazimierowicz M. (2008), Skuteczne zarzadzanie szkoła, ,,Nowa Szkoła”, 8.

Koźmiński A.K., Piotrowski W. (2010), Zarządzanie. Teoria i praktyka, Wydawnictwo Naukowe PWN, Warszawa.

Koźmiński A.K., Obój K. (1989), Zarys teorii równowagi organizacyjnej, Polskie Wydawnictwo Ekonomiczne, Warszawa.

Krzyżanowski L. (1999), O podstawach kierowania organizacjami inaczej, Wydawnictwo Naukowe PWN, Warszawa.

Kurzyna-Chmiel D. (2009), Podstawy prawne i organizacyjne oświaty, Wydawnictwo Naukowe PWN, Warszawa.

Kwiatkowski S.M., Michalak J.M. (2010), Przywództwo edukacyjne w teorii i praktyce, IBE, Warszawa.

Kwiatkowski S.M., Michalak J.M., Nowosad I. (red.) (2011), Przywództwo edukacyjne w szkole i jej otoczeniu, Difin, Warszawa.

Martynowicz E. (2003), Osoba jako autor działania [w:] B. Wojciszke, M. Plopa (red.), Osobowość a procesy psychiczne i zachowanie, Impuls, Kraków.

Maslow A. (1990), Motywacja i osobowość, Wydawnictwo PAX, Warszawa.

Mazurkiewicz G. (2012), Edukacja i przywództwo. Modele mentalne jako bariery rozwoju, Wydawnictwo Uniwersytetu Jagiellońskiego, Kraków.

Mazurkiewicz G., Dorczak R. (red.) (2015), Przywództwo edukacyjne. Próba zmiany, Wydawnictwo Uniwersytetu Jagiellońskiego, Kraków.

Michalak J.M. (2006), Przywództwo w szkole, Impuls, Kraków.

Mintzberg H. (1990), The Manager's Job: Folklore and Fact, „Harvard Buisiness Review”, March-April.

OECD (2012), Preparing Teachers and Developing School Leaders for 21 Century: Lesson From Around the World, OECD, Paris. 
Oleksyn T. (2010), Zarzadzanie kompetencjami. Teoria i praktyka, Oficyna a Wolters Kluwer business, Warszawa.

Oleksyn T. (2014), Zarządzanie zasobami ludzkimi w organizacji, Oficyna a Wolters Kluwer business, Warszawa.

Orczyk J. (2009), Wokół pojęć kwalifikacji i kompetencji, http://www.ipiss.com.pl/wp-content/uploads/downloads/2012/11/j_orczyk_zzl_3-4-2009.pdf [dostęp: 14.05.2017].

Penc J. (2007), Nowoczesne kierowanie ludźmi. Wywieranie wplywu i współdziałanie w organizacji, Difin, Warszawa.

Pervin L.A., John O.P. (2002), Osobowość - teoria i badania, Wydawnictwo Uniwersytetu Jagiellońskiego, Kraków.

Patterson F. (2001), Developments in Work Psychology: Emerging Issues and Future Trends, „Journal of Occupational and Organizational Psychology”, 74, 381-390.

Pielachowski J. (2001), Rozwój i awans zawodowy nauczyciela, Wydawnictwo eMPi2, Poznań.

Pielachowski J. (2007), Organizacja i zarządzanie oświata i szkoła, eMPi2, Poznań.

Pyżalski J. (2014), Kompetencje przywódcze dyrektorów szkót i placówek w krajach Unii Europejskiej oraz w Stanach Zjednoczonych, ORE, Warszawa.

Rada Unii Europejskiej (2013), Konkluzje Rady w sprawie skutecznego przywództwa edukacyjnego, Sekretariat Generalny Rady, Bruksela.

Riesman D. (2011), Samotny tłum, tłum. J. Strzelecki, Vis-à-vis/Etiuda, Kraków.

Rogers C. (1980) A Way of Being, Houghton Mifflin, Boston.

Rotter J. (1966), Generalized Expectancies for Internal vs External Control of Reinforcement, „Psychological Monographs, General and Applied”, 80 (1).

Rotter J. (1990), Poczucie wewnętrznej versus zewnętrznej kontroli wzmocnień, „Nowiny Psychologiczne", 5-6.

Rozporządzenie Ministra Edukacji Narodowej z 23 lutego 1999, Dz.U. Nr 14, poz. 126.

Sęk H., Brzeziński J., Domachowski W., Kowalik S. (1998), Społeczna psychologia kliniczna, Wydawnictwo Naukowe PWN, Warszawa.

Słownik języka polskiego (2005), Wydawnictwo Naukowe PWN, Warszawa.

Solgado J.F. (1997), The Five Factor Model of Personality and Job Performance in the European Community, „Journal of Applied Psychology”, 82.

Strykowski W. (2005), Kompetencje współczesnego nauczyciela, „Neodidagmata”, 27/28.

Szewczyk K. (2009), Bioetyka, t. 1: Medycyna na granicach życia, Wydawnictwo Naukowe PWN, Warszawa.

Thomas D.W., Holdaway E.A., Wardk L. (2000), Policies and Practices Involved in the Evaluation of School Principals, ,Journal of Personnel in Education”, 14, 215-240.

Tucker P.D., Young M.D., Koschoreck J.W. (2012), Leading Research-based Change in Educational Leadership Preparation: An Introduction, „Journal of Research on Leadership Education", 7, 155-171.

Tołwińska B. (2011), Kompetencje społeczne dyrektorów szkót, Impuls, Kraków.

Ustawa z dnia 7 września 1991 r. o systemie oświaty [UoSO] (tekst jednolity Dz.U. z 2004 r. Nr 256).

Ustawa z 26 stycznia 1982 r. - Karta Nauczyciela (tekst jednolity Dz.U. z 2014 r.).

Vallacher R.R., Wegner D.M. (1989), Levels of Personal Agency: Individual Variation in Action Identification, ,Journal of Personality \& Social Psychology”, 57. 
Witek S. (2000), Zarządzanie zreformowana szkoła, Wydawnictwo Naukowe PWN, Warszawa. Zawadzki B., Szczepaniak P., Strelau J. (1995), Diagnoza psychometryczna pięciu wielkich czynników osobowościowych: Adaptacja Kwestionariusza NEO-FFI Costy i McCrae do warunków polskich, „Studia Psychologiczne”, 33, 189-225.

Zieleniewski J. (1979), Organizacja i zarzadzanie, Polskie Wydawnictwo Ekonomiczne, Warszawa. 